Review

\title{
Land Use and Wildfire: A Review of Local Interactions and Teleconnections
}

\author{
Van Butsic *, Maggi Kelly and Max A. Moritz \\ Department of Environmental Science, Policy and Management. University of California Berkeley, \\ Berkeley, CA 94720, USA, E-Mails: maggi@berkeley.edu (M.K.); mmoritz@berkeley.edu (M.A.M.) \\ * Author to whom correspondence should be addressed; E-Mail: vanbutsic@berkeley.edu; \\ Tel.: +510-666-5400.
}

Academic Editor: Audrey L. Mayer

Received: 17 November 2014 / Accepted: 13 February 2015 / Published: 25 February 2015

\begin{abstract}
Fire is a naturally occurring process of most terrestrial ecosystems as well as a tool for changing land use. Since the beginning of history humans have used fire as a mechanism for creating areas suitable for agriculture and settlement. As fires threaten human dominated landscapes, fire risk itself has become a driver of landscape change, impacting landscapes through land use regulations and fire management. Land use changes also influence fire ignition frequency and fuel loads and hence alters fire regimes. The impact of these changes is often exacerbated as new land users demand alternative fire management strategies, which can impact land cover and management far from where land use change has actually occurred. This creates nuanced land use teleconnections between source areas for fires and economic cores, which demand and fund fire protection. Here we will review the role of fire and fire risk as a driver of land use change, the ways land use changes impact drivers of fire, and suggest that the integration of land use teleconnections into the fire/land use discussion can help us better understand and manage the complex interactions between fire and land use.
\end{abstract}

Keywords: wildfire; land use change; teleconnections; wildland urban interface (WUI); fire risk; regulations 


\section{Introduction}

The human relationship to fire is complex, and it varies substantially across the globe [1]. Humans have used fire as a tool for modifying landscapes for millennia, clearing land for agriculture, improved hunting, and settlement [2-5]. At the same time, human land use changes have had profound impacts on fire regimes by changing fuel loads and ignition rates, leading to altered fire patterns in many parts of the world [6]. Fire management, in response to human settlement on fire prone landscapes, has often led to ever greater manipulation of fire regimes, with near complete exclusion of fire in some systems resulting in massive changes to natural ecosystems $[7,8]$.

Natural controls on fire activity are dominated by climate variation [9], which can manifest itself at a variety of scales. Fire regimes — namely the sizes, frequencies, intensities, and seasonalities of fire - are typically quantified (i.e., through their statistical distributions) at the regional scale. There are three primary constraints underpinning the spatial and temporal patterns of fire activity: (1) the availability of resources to burn (fuel loads); (2) conditions conducive to combustion (length and intensity of fire season); and (3) ignitions (primarily human sources and lightning) [10]. More local factors, especially topography, can also emerge as an important influence in some fire-prone ecosystems. Therefore, a combination of global, regional, and local factors determines the characteristics of fire regimes.

Land use changes are also driven by forces acting at multiple scales [11]. Global, national, and region wide economic conditions are the largest drivers of aggregate land use change $[12,13]$. For the individual decision maker, however, local conditions - Including physical conditions of the land, the location of a given piece of land, and the nuanced preferences of the landowner can impact land use decisions $[14,15]$. Together, global and local drivers interact to create land use systems.

At both global and local scales land use decisions impact fire regimes. At the global scale, land use change contributes to climate change, which in turns impacts the regional climate variation that regulates fire regimes [16,17]. Locally, land use changes impact both fuel loads and ignitions, the primary regulators of local fire conditions. Hence, land use change has become a key driver of fire in many systems across multiple scales.

Beyond interactions across scales, land use and fire may also form unique teleconnections $[18,19]$. Teleconnections describe interactions that take place between non-adjacent locations, for example between urban centers and distant farms. We hypothesize here that teleconnections may exist between land use and fire due to funding mechanisms which directly link local land use change to distant fire management decisions and because management goals of local and distant actors may differ.

We believe that a land systems science framework for understanding the complex role of fire in society may be a valuable contribution to our understanding of human fire relationships. This is urgently needed, especially given the important role that land use plays in different fire-related problems across the globe [20]. Here, we attempt to synthesize the relationships between fire, its risk, and management, and land use change. We start by reviewing past research on the impacts of fire, fire risk and fire management on land use change as well as the impacts of land use change on fire ignitions and fuel loads. We will then offer a land change science perspective on fire and land use interactions drawing heavily on the idea of land use teleconnections [18]. In this section we focus on a short case study of teleconnections between land use and fire, fire risk, and fire management in California. Our goal is to demonstrate how a land change science perspective can broaden the suite of interactions that are evaluated 
within the land change/fire system. The inclusion of teleconnections within this system suggests the need to coordinate land change and fire management across large spatial scales and between non-adjacent areas.

\section{Fire, Fire Risk, and Fire Management of Risk as Drivers of Land Use Change}

\subsection{Fire as a Tool for Changing Landscapes}

Human use of fire to convert landscapes has ranged from localized and targeted applications to impacts across vast regions. For example, early Polynesian colonization of the south island of New Zealand coincided with apparent fire-driven changes in vegetation types, erosion rates, and lake chemistry [21]. Likewise, in North America the use of fire to increase game and grazing was a common strategy of native population and early settlers alike [5]. More recent tropical deforestation and conversion to agricultural is often accomplished through the use of fire, which can have devastating effects in rainforests [22,23]. Throughout history, and even today, fire is clearly an effective landscape-altering tool.

To describe how human use of fire on the landscape changes with increasing levels of industrialization, a general model of phases in a "pyric transition" has been proposed [1,6]. At one end of the spectrum is an uninhabited landscape with some existing background level of fire; intermediate stages see increasing fire activity as humans modify the landscape to suit their needs (i.e., land clearing, soil productivity, cooking and heating); and on completely urbanized landscapes of industrialized cultures, fire has been largely eliminated as a tool to convert landscapes and fossil fuels replace biomass as a source of energy for doing work. Spatial changes in fire, such as concentration in some areas and elimination in others, may also occur along this hypothetical gradient in development. One could imagine the pyric transition taking different forms in different cultures, though few quantitative demonstrations of it exist to date.

\subsection{Fire Risk and the Management of Fire Risk as Drivers of Land Use Change}

Fire risk and the management of this risk are also a driver of land use change, both by changing human behavior and by changing the regulatory framework in which land use change takes place. Individual tolerance for fire risk can impact land use change. Economic studies [24,25] of land use change have shown that some risk averse landowners are less likely to develop fire prone areas, although this aversion is often balanced by the fact that many fire prone areas also have natural amenities that are desired by home owners (for instance fire prone steep slopes may also offer wonderful views) [26,27]. While it is a common assumption in many fire prone areas that landowners typically rebuild after a fire, empirical evidence suggest that this is not always the case, and indeed a re-wilding of some previously subdivided land may take place after fires [28].

Local and state governments have often used fire risk and public safety as a lever to impact the planning and development process [29]. In the state of California, the state government has mapped areas of very severe fire hazard (VSFH) in municipalities and these areas can be under special development regulations [30]. In some municipalities local zoning has made these areas out of bounds for development, while in others it may be more difficult for developers to insure homes built in VSFH zones. While this policy has been criticized as not being strong enough to deter land use change [24,31], the intention of the regulation was to do just that. 
Likewise, the state of California recently passed a law requiring local authorities to include wildfire safely as part of general plans [32]. While this law has only recently passed, the goal is to force communities to think about how wildfire may impact future land use changes. At a smaller scale many municipalities now require that new developments have plenty of egress and regress for firefighting equipment and in addition many localities now enforce strict vegetation guidelines as another way to reduce fire risk [33]. All of these land use planning measures can impact the land-use change process by limiting areas where residential development can take place, the arrangement this development takes (for instance development densities), as well as vegetation near these developments.

The goal of many of these regulations is to change development patterns in fire prone areas - especially in the wildland urban interface (WUI). Thus far, however, there is little empirical evidence that these land use regulations actually reduce fire risk. While a few studies demonstrate how different housing arrangements may impact fire risk [34-36], more comprehensive analysis of such policies is an area of great research need.

Fire risk can also influence land use change through fire management. Often, increased land use intensity (especially increased housing density) results in an increased demand for fire management. In many systems this means manipulating fuel loads through prescribed burns, mastication, and the removal of fuels [37]. Fuel management can result in land use change by leading to type conversion of natural systems - the conversion of an ecosystem from one dominant vegetation type to another [38]. For instance, management of vegetation in chaparral-dominated systems is typically performed by masticating or burning shrubs. Non-native grasses can quickly invade the treated area and become the dominant vegetation type - indicating a type conversion from shrubs to grass [39,40]. This land cover change can then result in a land use change if livestock are brought in to graze the newly established grasses, which has historically constituted "range improvement" in much of the American West. In this setting fire risk leads to a land use transformation from a natural shrubland system to a low intensity agricultural system.

Vegetation management to reduce fire risk can change land use in forested systems in complex ways. In the United States, fire suppression efforts within Forest Service land was originally meant to protect these lands as productive timber stands. In some forests, suppression has increased to the point of total exclusion, at times increasing forest biomass [8]. In these forests a dense understory has grown which has increased the risk of catastrophic fires. In order to reduce this risk, the understory is now being manually cleared in many forests. In some forests, this cleared understory is being used as a source of biofuel to generate electricity. Thus, fire risk can led to a complex change where fire management can transform forest production and use.

An unintended consequence of intentionally reducing fire risk, through both government-subsidized fire suppression and fuels reduction projects, may actually be increased development and human exposure to losses on some fire-prone landscapes [20]. This is because fire risk is only marginally and temporarily reduced through these publicly funded activities, which could promote the perception that such development is acceptable and reasonably safe. Similar to the "safe development paradox" observed to operate on flood-prone landscapes [41], fire risk management can have somewhat perverse outcomes that feed back to cause further land use change and ultimately increased exposure to losses. 


\section{The Impacts of Land Use Change on Drivers of Fire Risk}

Land use change is not only driven by fire and fire risk, it feeds back and impacts fire regimes through changing ignition frequency, fuel loads, and once again management. The overall impact of land use change on drivers of fire risk is often specific to the location, ecosystem, land use system, and underlying climate of a particular place, and thus it can be difficult to generalize across multiple systems, although some general trends have emerged. While fuel loads and ignition are often good indicators of fire risk, this relationship can also be complicated through fire suppression, fuels management and a host of other factors [20]. Indeed, in some cases high fire frequency can be correlated with low fire risk, if fires are started in areas with low chances of spreading $[42,43]$. Therefore, we present the impact of land use change on ignition frequency and fuel loads, with the understanding that the total impact of these drivers on fire risk may be complex.

\subsection{Land Use Change and Ignition Frequency}

The trend in much of the world is towards landscapes with more ignitions [44], and these ignitions are often associated with increased land-use intensity [45,46]. This is because in most areas humans are responsible for starting most fires. Although the majority of human caused ignitions are accidental, arson is also a major cause of fire globally and tends to increase with land use intensity. Interestingly, the correlation between increased ignitions and land use intensity may date back to pre-European settlement [47] in North America. Across many land uses increased intensification through the expansion of roads $[48,49]$ has been identified as a major cause of increased ignitions.

In regions with high fire risk, ignitions may be highest at intermediate housing densities [50-52] making the WUI particularly fire prone. Within the WUI, different land uses and densities may lead to different ignition frequencies although the absolute density, which leads to maximum ignitions seems to vary across regions. Some researchers have found isolated houses within the WUI lead to the most ignitions [53,54] while others have found clustered houses have more ignitions [50]. In areas of very high housing densities, ignition rates may be low because even though there are ample sources of ignitions, most materials simply are not flammable. Likewise, at very low housing densities most ignitions tend to be from natural causes such as lightning strikes. Thus, there is strong empirical evidence for a humped shaped relationship between ignitions and housing density, with the peak of the function at intermediate densities.

Changing agricultural uses can also change ignitions. Agricultural abandonment may increase fire at times [55] if abandoned fields are fire prone. This may be especially true in Mediterranean climates where shrublands may burn more frequently than active agricultural lands [56]. Likewise shrubland fires may be larger than others in agricultural lands [57,58]. Conversely there is also evidence that increased livestock density may increase ignitions [59] especially if farmers use burning to spur vegetation regrowth. There is evidence that farm size may influence ignitions, with larger farms having more fires, although it is not clear if these fires are accidental or not [60]. This relationship may actually change seasonally and geographically [61].

\subsection{Land Use Change and Fuel Loads}

Land use change can increase or decrease the amount of fuel on the landscape, relative to natural systems. Low density housing can lead to increased fuel loads if houses are not designed with flame 
resistant materials, if homeowners plant flammable vegetation near their homes, or if the natural ecosystems housing replaces have low fuel loads. Alternatively, small scale fuel treatments associated with increased housing density can decrease fuel loads [62,63] although different ownership types may be more or less likely to manage fuels. Increased land use intensity can result in decreased fuel loads, as is the case in dense cities where most buildings are built from non-flammable concrete and steel.

Changes in agricultural systems can also impact fuel loads. The decline of traditional grazing agriculture has increased fuel loads in Portugal [48] and Spain [55] and is associated with land abandonment and shrub encroachment [64] in other Mediterranean countries. However, grazing techniques are also used frequently to reduce fuel loads in natural areas. Likewise, as farms increase intensity from grazing to row crops, typically fuels decrease. Agricultural abandonment and forest regrowth may lead to increased fuel loads, as seen in some areas of Eastern Europe.

\section{Fire and Land Use Feedbacks and Teleconnections-A Case Study of California Fire Management}

Thus far we have reviewed the relationships between fire and land use change by focusing on how fire and fire risk can impact land use change and how changing landscapes can impact ignitions and fuel loads, common drivers of fire risk. Most of the research reviewed here has been concerned with the local interactions between fire and land use (Figure 1). In this section we expand this local perspective by hypothesizing that land use changes in one location can impact fire, and eventually land use, in distant locations.

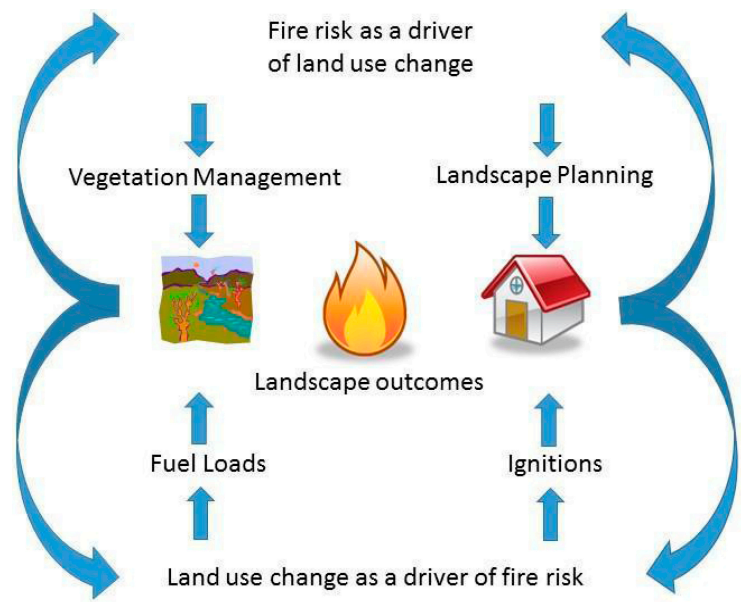

Figure 1. Conceptual model of interactions between land use changes and fire risk. Fire risk can drive land use change by creating the need for alternative vegetation management activities, such as type converting flammable fuels and landscape planning, such as laws that dictate suitable areas for subdivision based on wildfire risk. Land use change can in turn impact fire risk by impacting fuel loads and ignitions. Combined, these impacts interact on the landscape and thus inform both future land use change decisions and future fire risk. This creates a feedback-laden system where the actions in one time period may impact future actions.

The land use change fire nexus fits well within the emerging concepts of land use teleconnections [18]. Land use teleconnections are a way to describe the connections between land use in areas that are not necessarily geographically close to each other, but none-the-less exert forces on each other $[65,66]$. 
Fire and climate teleconnections have been well documented [67-70], as climatic forces distant from actual fires can impact fire frequency and size. We hypothesize that similar connections may occur between land use and fire: Land use decisions in one place may impact fire management in distant places. Likewise, local fire management decisions may impact distant land use decisions as well. Here we will describe land use and fire management within California's fire management system and then hypothesize that at least three potential teleconnections exist within this system.

\subsection{California's Fire and Land Management System}

California is one of the most fire prone places in the United States and over 1000 homes are lost to wildfire in the state every year. Fire was used frequently by the Native Californians and widespread on the landscape in pre-European-American settlement era. Some estimates of prehistoric annual area burned in California (up to 1.8 million ha annually) are much higher than current rates and some researchers claim many Californian ecosystems have a fire deficit [71]. Low and moderate-severity fires are not as societally challenging or expensive as larger, catastrophic fires that can do widespread damage especially in WUI areas.

Responsibility for fire protection falls broadly into three categories and is determined by whether land is within a municipality, the intensity of its use, and if it is owned by the federal government. Local responsibility areas (LRAs) include all incorporated lands in the state, such as villages, towns and cities as well as unincorporated areas in intensive agricultural uses (such as row crops, but excluding most pasture and rangelands). Within the LRAs municipal fire agencies typically are responsible for controlling fire and managing vegetation and funds for fire management are generated through local property taxes and sometimes local bond measures. Unincorporated areas of the state with housing densities under three dwellings per acre, including private, county, and state owned land, as well as low intensity agricultural lands are part of the state responsibility area (SRAs). Fire management in the SRA is performed by CALFIRE the California statewide fire agency (although in a minority of counties CALFIRE contracts out fire protection to county governments). Funding for CALFIRE comes from both the state general fund, as well as the fire prevention fee, a fee of $\sim \$ 150.00$ charged to landowners for each habitable structure owned in the SRA. The fire prevention fee was first applied to SRA land in 2013 and how these funds are used and indeed whether the fee should be in place at all are contentious issues. Finally, federal responsibility areas (FRAs) include all of the federally managed lands in the state including national forest, national park, BLM, national monument and military lands. Money for fire prevention activities in these areas usually comes from federal sources (Figure 2).

Land use change is generally determined by market forces interacting with local, state, and federal land use regulations. Within LRA's municipalities are generally responsible for land use planning, although some LRA land that is in intense agricultural use is subject to planning by the county government. Planning in SRA land is typically done at the county level, although each county is required by California state law to have a general plan which meets a number of health, safety and environmental goals. Finally, federal lands are managed to meet the goals of the federal government. The ability of local actors to influence federal management is a point of contention throughout the state. All development decisions in the state are subject to federal environmental laws such as the endangered species act. 


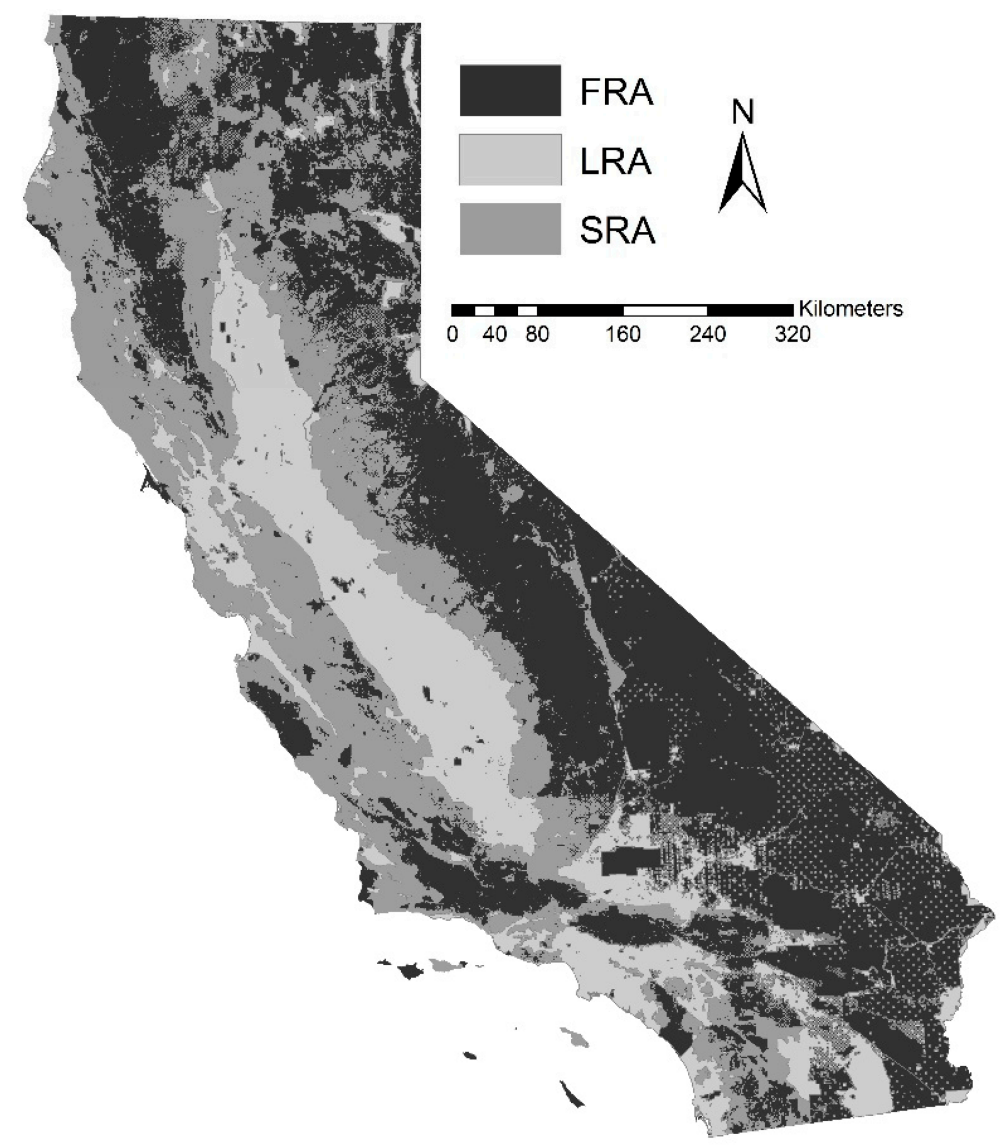

Figure 2. State, Local and Federal, Responsibility Areas, in the state of California (all data provided by CalFire [72]).

Probably the most striking land use changes in California since the 1950's have been the expansion of housing into formerly agricultural and natural areas [73]. Much of this growth has taken place in the WUI [74,75] creating dynamic patterns of land use change where the LRA, SRA and FRA land meet. In many ways, growth in California's WUI is likely typical of much of the rest of the US [76] and therefore may be a useful lens to look at broadly applicable teleconnections. Likewise, conditions in other locations globally, for instance connections between land use and fire management in Australia after the 2009 Victoria fires, may have similar dynamics [77,78].

\subsection{Hypothesized Local Feedbacks and Teleconnections}

Within this regulatory land use and fire framework, we hypothesize a number of interesting land use teleconnections exists (Figure 3). In particular, the establishment of the fire prevention fee in 2013 creates a unique link between local land use decisions, the statewide fire management budget, and ultimately fire management and land uses throughout the state. We focus here on land use change dynamics, and how these may form both local and teleconnections with fire. 


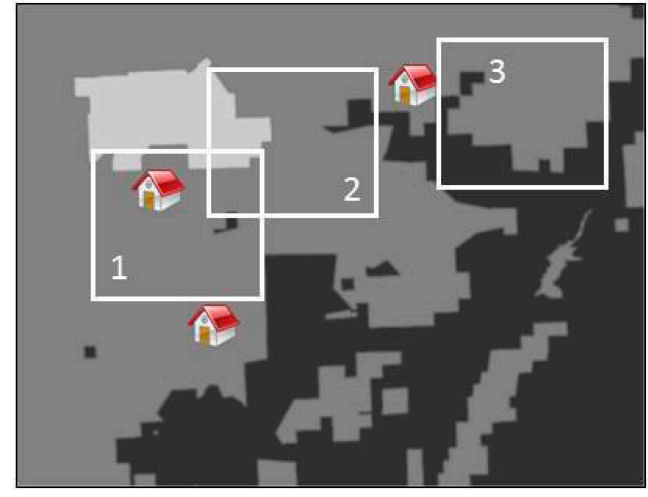

LRA Land

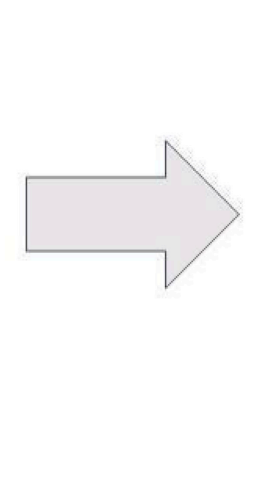

SRA Land

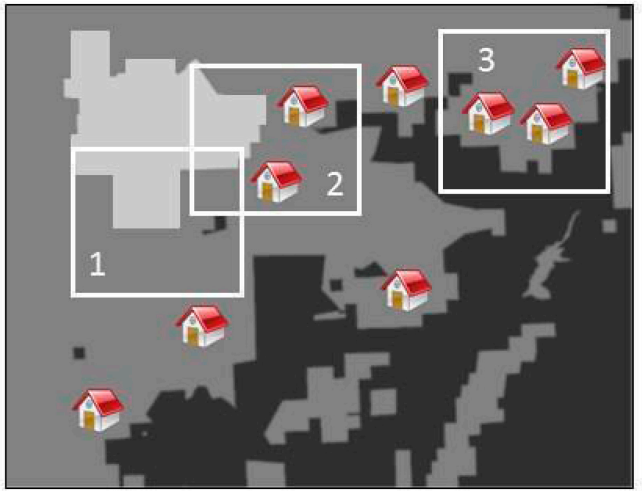

FRA Land

Figure 3. Dynamics of land use change and fire. In box 1, a low-density rural housing in the State Responsibility Area (SRA) is annexed by Local Responsibility Area (LRA) community. In this process SRA fire management loses funds as SRA fees are no-longer collected in this area. In box two SRA land develops at a low enough density so that it does not switch to LRA management. This will increase firefighting revenue for Calfire, but may also increase fire risk as low-density housing is correlated with high fire risk in much of the state. Given the location of this development this may also increase fire risk for areas within the LRA. Box three shows increased housing density near Federal Responsibility Area land. These new homeowners may demand more stringent fuels management within the FRA, although management decisions may be undertaken from within goals of the broader public in mind.

\subsubsection{Teleconnection 1: Annexation of SRAs by Municipalities Leads to Potential Changes in Fire} Management Statewide

When municipalities annex outlying areas for development, these lands will switch from SRA to LRA classification, because municipalities are generally responsible for their own fire protection. This change in administration has multiple impacts on the management of land and its potential uses. Locally, the annexation may impact land use decisions and potentially fire risk. If the annexed areas develop at densities higher than the SRA designation, a common reason why annexation would take place, we may expect fire risk will change as well. Likewise, these changes may impact the fire risk to nearby SRA land, which may ultimately impact local SRA management. Finally, properties that are annexed no longer need to pay the fire prevention fee (although land owners may be required to pay new local taxes for fire management), therefore reducing funds to statewide fire management.

The main teleconnection is the impact of local administrative changes on funding for the statewide fires protection program. Annexation reduces funding for statewide fire protection for SRAs since fire prevention fees are shared across the state. The strength of this teleconnection may be exacerbated since the fire prevention fee is based on the number of dwellings on a property, not the size of the property. Areas of the SRA which are relatively densely populated-For instance some WUI areas surrounding larger cities - Contribute more to the SRA fire prevention funding on a per acre basis than areas with fewer structures. These areas may also be the most likely to be annexed because they are often adjacent to municipalities. Over time, we expect that land use change which drives annexation of more densely 
populated SRA areas may lead to fewer SRA fess on a per acre basis for the properties remaining in the SRA. While this dynamic will likely reduce SRA fees on a per-acre basis, if fire risk is most highly associated with low density development which may be common in annexed properties, the average fire risk to SRA parcels may be lowered after annexation as well. In sum, the connection between annexation, SRA fees and statewide fire management is complex. What is clear, however, is that local decisions to annex land can have impacts on fire management well beyond local areas.

\subsubsection{Teleconnection 2: SRA Administration May Encourage Local Low Density Development, Increase Statewide Fire Management Funds but Potentially Costs As Well}

If land in the SRA converts from low intensity agriculture or forestry to low intensity housing (anything below three dwellings per acre), the property can stay in SRA, as long as it is not annexed by a municipality. In such a case the landowner now must pay the SRA fee for any structures built, increasing SRA fees statewide. This creates an interesting local incentive for counties to develop at low densities: Counties can gain increased tax revenue from the new structures, but as long as the density of these structures are low enough, fire protection remains the responsibility of the state (or at least partially - Many low density communities split firefighting duties between state and local authorities). Locally, there are many potential dynamics of these incentives. For one, counties gain tax revenue while taking on little firefighting costs. Likewise, in the common case where low-density housing is fire prone, nearby LRAs may end up spending more on fire management if SRA areas become more hazardous.

The local decision to develop at low densities in SRAs also has statewide implications as well, creating land use teleconnections. The initial implication is an increase in revenue for statewide fire management because all new structures will be required to pay the fire prevention fee. These fees can be used anywhere in the state and therefore may impact land far away from the structure on which the fee was levied. However, if a county allows a large amount of low-density SRA developments, and this development is commonly associated with increased fire risk, over time the cost of fire management may outweigh the fees generated by the new structures. If this is the case, the county may become a "sink" for SRA fees - More may be spent locally on fire management then are contributed via SRA fees. This would imply that SRA in a different part of the state are subsidizing this areas fire management and in turn are receiving less fire management then they would in the absence of the new low density development. The teleconnection between new SRA developments and statewide fire management can therefore increase or be a drain on state fire management resources depending on how the new developments impact fire risk.

\subsubsection{Teleconnection 3: Local, State and Federal Land Use and Fire Management Decisions Interact across Administrative Boundaries}

Finally, we hypothesize that there are strong land use teleconnections between land use change on LRA and SRA lands, and fire management and land use change on FRA lands. Federal lands management in the west is often contentious and in California competing land uses outside of the FRA demand alternative land uses and fire management strategies within FRAs. California, like other states has seen an increase in housing density in areas around federal forest and parks [79]. As homes are built closer to wildlands, there may be a heightened demand to prevent fires from spreading from FRA land to SRA or LRA land. These concerns may also be held by timberland owners near FRAs who have 
recently lost valuable timber when fire has spread from FRA land to SRA land. In this way, there is a local connection between land use decisions near the FRA and management within the FRA. Likewise, if development around FRA's is at typical WUI densities, these developments likely increase the chance for fires, which may spread from SRA or LRA lands to federal property. FRA managers therefore have an incentive to try to reduce fire in non-FRA land close to FRAs, especially fires ignited by humans. Thus, there are strong local connections between FRAs, SRAs and LRAs.

Teleconnections exists between FRA, SRA, and LRA lands because management of FRA land is also influenced by non-local actors and the experience of federal land managers far from California. For example, policies to suppress or let burn wildfire in the FRA are informed not simply by what would be optimal locally, but with management of the full portfolio of federal land in mind. Therefore, even though suppression of a given fire may benefit local actors, this may not be the choice of made by federal agencies with massive land holdings. Goals that may be less important than fire protection to local landowners - Such as biodiversity production and aesthetic quality —often play a large role FRA management. This creates a tension between the scale at which fire prevention activities should take place, and the balance of local versus national interest on federally managed lands.

\section{Future Research Directions and Policy Implications}

Fire and land use are parts of a coupled system, and research discovering and incorporating these dynamics is limited. We have reviewed a number of manuscripts that answer directional questions such as "what is the impact of housing density on fire ignitions/fuel loads" or "what regulations have been put in place to encourage fire safe land use" however far fewer have attempted to address such questions jointly. To do so requires a coupled systems approach that addresses both the natural side of fire and land use-For example how fires spread through different fuels and over different terrain-As well as the human dimensions of land use change and fire management - Such as land use planning decisions and vegetation management. Previous attempts to model the fire and land use system have typically combined spatially explicit land use change and fire behavior models in order to assess the impact of land use change on fire risk [52,80]. While these models have been useful in showing many of the dynamics of the coupled systems they could still be improved by more fully integrating feedbacks between human and natural systems, uncertainty over time and space, and by being more explicitly grounded in theories of human behavior.

Second, as we have pointed out, there may be strong teleconnections between land use and fire decisions. Modeling these teleconnections will require expanding the approaches currently used in the coupled-systems literature to account for interactions between distant places. Modeling and quantifying interactions from possibly distant drivers is difficult, although there are a number of recent examples within the land use literature which may give guidance to researchers interested in the fire and land use teleconnections $[12,81]$. That being said, developing new approaches that are able to account for land use/fire teleconnections should be a priority area of research.

There is a mature literature demonstrating the strong local connections between land use change and fire. From a policy perspective, then, our review supports the quite obvious policy measure that fire should be taken into account in any land-use planning endeavor [20]. And yet, to our knowledge integrating wildfire and land use planning is quite rare. While the State of California now requires 
wildfire planning in its county plans, and some Australian regions have similar laws [82] our research indicates that many regions still do not coordinate land use planning and wildfire prevention. This is perhaps due to the outdated thought that fire is a destructive force to be eliminated, rather than a force that can be planned for [83]. In light of the strong impacts of land use change on fire and vice versa, our view is that large gains to public safety could be made through better coordination between planning and firefighting agencies.

The presence of teleconnections between fire and land use change may indicate that coordination of fire and planning at the local level may be insufficient. This is especially true in an area like California where firefighting funds may come from local, state, or federal sources. In such situations land use change can impact firefighting resources in distant places and hence there may be a need for more concentrated planning and fire management at the state level. Or at the least funding for statewide programs may be better off separated from local land use decisions. This could be done by guaranteeing that local SRA fees are returned to the county they originate.

\section{Conclusions}

Fire and land use have been connected throughout history. Here we provide a relevant review of many of these connections, including the impacts of fire on land use and land use regulations, and also the impacts of land use on fire ignitions and fuel loads. While our review is not exhaustive, it does suggest that even though there are clear feedbacks between land use and fire, they are still often studied as a closed rather than coupled system. This may be changing however, as recent research has shown promise in this area $[20,84,85]$. We suggest that future research into fire and land use as a coupled system is necessary to provide pathways to a future where we co-exist with fire as a natural process, and when possible, better plan how and where we build.

Furthermore, as the case study of California fire management demonstrates, teleconnections between distant places can also impact the fire land use nexus. With funding, land use, and management decisions often being decided by forces outside of local jurisdiction, useful research must take a broader view of the connections between fire and land use. This means adapting research techniques, such as modeling land use change and fire risk, such that they can account for forces that may be acting from outside of the traditional study areas.

\section{Author Contributions}

All authors contributed to the development, research, and writing of this manuscript.

\section{Conflicts of Interest}

The authors declare no conflict of interest.

\section{References}

1. Pyne, S.J. Fire: A Brief History; Jeremy Mills Publishing: West Yorkshire, UK, 2001; p. 204.

2. Pausas, J.G.; Keeley, J.E. A burning story: The role of fire in the history of life. Bioscience 2009, 59, 593-601. 
3. Karkanas, P.; Shahack-Gross, R.; Ayalon, A.; Bar-Matthews, M.; Barkai, R.; Frumkin, A.; Gopher, A.; Stiner, M.C. Evidence for habitual use of fire at the end of the Lower Paleolithic: Site-formation processes at Qesem Cave, Israel. J. Hum. Evol. 2007, 53, 197-212.

4. Bar-Yosef, O. The upper Paleolithic Revolution. Annu. Rev. Anthropol. 2002, 31, 363-393.

5. Stephens, S.L.; Martin, R.E.; Clinton, N.E. Prehistoric fire area and emissions from California's forests, woodlands, shrublands, and grasslands. For. Ecol. Manag. 2007, 251, 205-216.

6. Bowman, D.M.J.S.; Balch, J.; Artaxo, P.; Bond, W.J.; Cochrane, M.A.; D’Antonio, C.M.; Defries, R.; Johnston, F.H.; Keeley, J.E.; Krawchuk, M.A.; et al. The human dimension of fire regimes on Earth. J. Biogeogr. 2011, 38, 2223-2236.

7. Fry, D.L.; Stephens, S.L.; Collins, B.M.; North, M.P.; Franco-Vizcaíno, E.; Gill, S.J. Contrasting spatial patterns in active-fire and fire-suppressed Mediterranean climate old-growth mixed conifer forests. PLoS One 2014, 9, e88985.

8. Collins, B.M.; Everett, R.G.; Stephens, S.L. Impacts of fire exclusion and recent managed fire on forest structure in old growth Sierra Nevada mixed-conifer forests. Ecosphere 2011, 2, 51.

9. Krawchuk, M.A.; Moritz, M.A. Constraints on global fire activity vary across a resource gradient. Ecology 2011, 92, 121-132.

10. Krawchuk, M.A.; Moritz, M.A.; Parisien, M.-A.; van Dorn, J.; Hayhoe, K. Global pyrogeography: The current and future distribution of wildfire. PLoS One 2009, doi:10.1371/journal.pone.0005102.

11. Turner, B.L.; Lambin, E.F.; Reenberg, A. The emergence of land change science for global environmental change and sustainability. Proc. Natl. Acad. Sci. 2007, 104, 20666-20671.

12. Lambin, E.F.; Meyfroidt, P. Global land use change, economic globalization, and the looming land scarcity. Proc. Natl. Acad. Sci. USA 2011, 108, 3465-3472.

13. Golub, A.; Hertel, T.W. Global economic integration and land use change. J. Econ. Integr. 2008, 23, 463-488.

14. Lewis, D.J.; Provencher, B.; Butsic, V. The dynamic effects of open-space conservation policies on residential development density. J. Environ. Econ. Manag. 2009, 57, 239-252.

15. Irwin, E.G.; Bell, K.P.; Bockstael, N.E.; Newburn, D.A.; Partridge, M.D.; Wu, J. The economics of urban-rural space. Annu. Rev. Resour. Econ. 2009, 1, 435-459.

16. Pielke, R.A., Sr. Land use and climate change. Science 2005, 310, 1625-1626.

17. Foley, J.A.; DeFries, R.; Asner, G.P.; Barford, C.; Bonan, G.; Carpenter, S.R.; Chapin, F.S.; Coe, M.T.; Daily, G.C.; Gibbs, H.K.; et al. Global consequences of land use. Science 2005, $309,570-574$.

18. Seto, K.C.; Reenberg, A.; Boone, C.G.; Fragkias, M.; Haase, D.; Langanke, T.; Marcotullio, P.; Munroe, D.K.; Olah, B.; Simon, D. Urban land teleconnections and sustainability. Proc. Natl. Acad. Sci. USA 2012, 109, 7687-7692.

19. Liu, J.; Hull, V.; Batistella, M.; DeFries, R.; Dietz, T.; Fu, F.; Hertel, T.W.; Izaurralde, R.C.; Lambin, E.F.; Li, S.; et al. Framing sustainability in a telecoupled world. Ecol. Soc. 2013, 18, 26.

20. Moritz, M.A.; Batllori, E.; Bradstock, R.A.; Gill, A.M.; Handmer, J.; Hessburg, P.F.; Leonard, J.; Odion, D.C.; McCaffrey, S.; Schoennagel, T.; et al. Learning to coexist with wildfire. Nature 2014, $515,58-66$. 
21. McWethy, D.B.; Whitlock, C.; Wilmshurst, J.M.; McGlone, M.S.; Fromont, M.; Li, X.; Dieffenbacher-Krall, A.; Hobbs, W.O.; Fritz, S.C.; Cook, E.R. Rapid landscape transformation in South Island, New Zealand, following initial Polynesian settlement. Proc. Natl. Acad. Sci. USA 2010, 107, 21343-21348.

22. Cochrane, M.A. Tropical Fire Ecology; Springer: Berlin, Germany, 2009.

23. Cochrane, M.A. Fire science for rainforests. Nature 2003, 421, 913-919.

24. Mueller, J.; Loomis, J.; González-Cabán, A. Do repeated wildfires change homebuyers' demand for homes in high-risk areas? A hedonic analysis of the short and long-term effects of repeated wildfires on house prices in Southern California. J. Real Estate Financ. Econ. 2009, 38, 155-172.

25. Mueller, J.M.; Loomis, J.B. Does the estimated impact of wildfires vary with the housing price distribution? A quantile regression approach. Land Use Policy 2014, 41, 121-127.

26. Hansen, W.D.; Naughton, H.T. The effects of a spruce bark beetle outbreak and wildfires on property values in the wildland-urban interface of south-central Alaska, USA. Ecol. Econ. 2013, 96, 141-154.

27. Donovan, G.H.; Champ, P.A.; Butry, D.T. Wildfire risk and housing prices: A case study from Colorado Springs. Land Econ. 2007, 83, 217-233.

28. Alexandre, P.; Mockrin, M. Rebuilding and housing development after wildfires. Int. J. Wildfire Res. 2015, in press.

29. Jacobs, H.M. Who Owns America; University of Wisconsin Press: Madison, WI, USA, 1998; pp. 29-44.

30. CA Government Code Section 51175-51189; California Government: Sacramento, CA, USA, 1993.

31. Troy, A.; Romm, J. Living on the Edge-Economic, Institutional and Management Perspectives on Wildfire Hazard in the Urban Interface (Advances in the Economics of Environmental Resources); Emerald Group Publishing: Bingley, UK, 2007; Volume 6, pp. 101-119.

32. Stephens, J. Land Use Laws 2012. Available online: http://www.cp-dr.com/node/3272 (accessed on 4 July 2014).

33. City of San Diego Brush Managment Regulations; City of San Diego: San Diego, CA, USA, 2013; pp. 1-3.

34. Paveglio, T.B.; Prato, T.; Hardy, M. Simulating effects of land use policies on extent of the wildland urban interface and wildfire risk in Flathead County, Montana. J. Environ. Manag. 2013, 130, 20-31.

35. Spyratos, V.; Bourgeron, P.S.; Ghil, M. Development at the wildland-urban interface and the mitigation of forest-fire risk. Proc. Natl. Acad. Sci. USA 2007, 104, 14272-14276.

36. Syphard, A.D.; Keeley, J.E.; Massada, A.B.; Brennan, T.J.; Radeloff, V.C. Housing arrangement and location determine the likelihood of housing loss due to wildfire. PLoS One 2012, 7, e33954.

37. Wondzell, S.M.; Burnett, K.M.; Kline, J.D.; Wales, B.C.; Suring, L.H.; Hemstrom, M.A. Modeling potential outcomes of fire and fuel management scenarios on the structure of forested habitats in northeast Oregon, USA. Landsc. Urban Plan. 2007, 80, 223-236.

38. Keeley, J.E. Fire management impacts on invasive plants in the Western United States. Conserv. Biol. 2006, 20, 375-384.

39. Potts, J.B.; Stephens, S.L. Invasive and native plant responses to shrubland fuel reduction: Comparing prescribed fire, mastication, and treatment season. Biol. Conserv. 2009, 142, 1657-1664. 
40. D'Antonio, C.M.; Vitousek, P.M. Biological invasions by exotic grasses, the grass/fire cycle, and global change. Annu. Rev. Ecol. Syst. 1992, 23, 63-87.

41. Burby, R.J. Hurricane Katrina and the paradoxes of government disaster policy: Bringing about wise governmental decisions for hazardous areas. Ann. Am. Acad. Pol. Soc. Sci. 2006, 604, 171-191.

42. Calef, M.P.; McGuire, A.D.; Chapin, F.S. Human influences on wildfire in Alaska from 1988 through 2005: An analysis of the spatial patterns of human impacts. Earth Interact. 2008, 12, 1-17.

43. De Wilde, L.; Chapin, F.S. Human impacts on the fire regime of interior Alaska: Interactions among fuels, ignition sources, and fire suppression. Ecosystems 2007, 9, 1342-1353.

44. Moreira, F.; Viedma, O.; Arianoutsou, M.; Curt, T.; Koutsias, N.; Rigolot, E.; Barbati, A.; Corona, P.; Vaz, P.; Xanthopoulos, G.; et al. Landscape-Wildfire interactions in southern Europe: Implications for landscape management. J. Environ. Manag. 2011, 92, 2389-2402.

45. Sadasivuni, R.; Cooke, W.H.; Bhushan, S. Wildfire risk prediction in southeastern Mississippi using population interaction. Ecol. Modell. 2013, 251, 297-306.

46. Dondo Bühler, M.; de Torres Curth, M.; Garibaldi, L.A. Demography and socioeconomic vulnerability influence fire occurrence in Bariloche (Argentina). Landsc. Urban Plan. 2013, 110, 64-73.

47. Holz, A.; Veblen, T.T. The amplifying effects of humans on fire regimes in temperate rainforests in western Patagonia. Palaeogeogr. Palaeoclimatol. Palaeoecol. 2011, 311, 82-92.

48. Nunes, A.N. Regional variability and driving forces behind forest fires in Portugal—An overview of the last three decades (1980-2009). Appl. Geogr. 2012, 34, 576-586.

49. Lein, J.K.; Stump, N.I. Assessing wildfire potential within the wildland-urban interface: A southeastern Ohio example. Appl. Geogr. 2009, 29, 21-34.

50. Chas-Amil, M.L.; Touza, J.; García-Martínez, E. Forest fires in the wildland-urban interface: A spatial analysis of forest fragmentation and human impacts. Appl. Geogr. 2013, 43, 127-137.

51. Syphard, A.D.; Radeloff, V.C.; Keeley, J.E.; Hawbaker, T.J.; Clayton, M.K.; Stewart, S.I.; Hammer, R.B. Human influence on California fire regimes. Ecol. Appl. 2007, 17, 1388-1402.

52. Syphard, A.D.; Radeloff, V.C.; Hawbaker, T.J.; Stewart, S.I. Conservation threats due to human-caused increases in fire frequency in Mediterranean-climate ecosystems. Conserv. Biol. 2009, 23, 758-769.

53. Lampin-Maillet, C.; Jappiot, M.; Long, M.; Morge, D.; Ferrier, J.-P. Characterization and mapping of dwelling types for forest fire prevention. Comput. Environ. Urban Syst. 2009, 33, 224-232.

54. Lampin-Maillet, C.; Long-Fournel, M.; Ganteaume, A.; Jappiot, M.; Ferrier, J.P. Land cover analysis in wildland-urban interfaces according to wildfire risk: A case study in the South of France. For. Ecol. Manag. 2011, 261, 2200-2213.

55. Ruiz-Mirazo, J.; Martínez-Fernández, J.; Vega-García, C. Pastoral wildfires in the Mediterranean: Understanding their linkages to land cover patterns in managed landscapes. J. Environ. Manage 2012, 98, 43-50.

56. Carmo, M.; Moreira, F.; Casimiro, P.; Vaz, P. Land use and topography influences on wildfire occurrence in northern Portugal. Landsc. Urban Plan. 2011, 100, 169-176.

57. Attiwill, P.; Binkley, D.; Adams, M.A. Mega-fires, tipping points and ecosystem services: Managing forests and woodlands in an uncertain future. For. Ecol. Manag. 2013, 294, 250-261. 
58. Ganteaume, A.; Camia, A.; Jappiot, M.; San-Miguel-Ayanz, J.; Long-Fournel, M.; Lampin, C. A review of the main driving factors of forest fire ignition over Europe. Environ. Manag. 2013, $51,651-662$.

59. Oliveira, S.; Oehler, F.; San-Miguel-Ayanz, J.; Camia, A.; Pereira, J.M.C. Modeling spatial patterns of fire occurrence in Mediterranean Europe using multiple regression and random forest. For. Ecol. Manag. 2012, 275, 117-129.

60. Jongman, R.G.H.; Martín-Martín, C.; Bunce, R.G.H.; Saura, S.; Elena-Rosselló, R. Changes and interactions between forest landscape connectivity and burnt area in Spain. Ecol. Indic. 2013, 33, 129-138.

61. Bajocco, S.; Pezzatti, G.B.; Mazzoleni, S.; Ricotta, C. Wildfire seasonality and land use: When do wildfires prefer to burn? Environ. Monit. Assess. 2010, 164, 445-452.

62. Fernandes, P.M. Fire-smart management of forest landscapes in the Mediterranean basin under global change. Landsc. Urban Plan. 2013, 110, 175-182.

63. Attiwill, P.; Binkley, D.; Ganteaume, A.; Jappiot, M. What causes large fires in Southern France. For. Ecol. Manag. 2013, 294, 76-85.

64. Silva, J.S.; Vaz, P.; Moreira, F.; Catry, F.; Rego, F.C. Wildfires as a major driver of landscape dynamics in three fire-prone areas of Portugal. Landsc. Urban Plan. 2011, 101, 349-358.

65. Güneralp, B.; Seto, K.C.; Ramachandran, M. Evidence of urban land teleconnections and impacts on hinterlands. Curr. Opin. Environ. Sustain. 2013, 5, 445-451.

66. Verburg, P.H.; Neumann, K.; Nol, L. Challenges in using land use and land cover data for global change studies. Glob. Chang. Biol. 2011, 17, 974-989.

67. Holz, A.; Kitzberger, T.; Paritsis, J.; Veblen, T.T. Ecological and climatic controls of modern wildfire activity patterns across southwestern South America. Ecosphere 2012, doi:10.1890/ES12-00234.1.

68. Norman, S.P.; Taylor, A.H. Tropical and north Pacific teleconnections influence fire regimes in pine-dominated forests of north-eastern California, USA. J. Biogeogr. 2003, 30, 1081-1092.

69. Le Goff, H.; Flannigan, M.D.; Bergeron, Y.; Girardin, M.P. Historical fire regime shifts related to climate teleconnections in the Waswanipi area, central Quebec, Canada. Int. J. Wildland Fire 2007, $16,607$.

70. Swetnam, T.W.; Betancourt, J.L. Fire-southern oscillation relations in the southwestern United States. Science 1990, 249, 1017-1020.

71. North, M.; Collins, B.M.; Stephens, S. Using fire to increase the scale, benefits, and future maintenance of fuels treatments. J. For. 2012, 110, 392-401.

72. Calfire, SRA, LRA, and FRA Data. Available online: http://frap.cdf.ca.gov/data/f rapgisdata-subset.php (accessed on 24 February 2015).

73. Pincetl, S. Transforming California, The Political History Of Land Use And Developemnt, 1st ed.; Johns Hopkins University Press: Baltimore, MD, USA, 2003.

74. Hammer, R.B.; Radeloff, V.C.; Fried, J.S.; Stewart, S.I. Wildland-urban interface housing growth during the 1990s in California, Oregon, and Washington. Int. J. Wildland Fire 2007, 16, 255.

75. Radeloff, V.; Hammer, R.; Stewart, S.; Fried, J.; Holcomb, S.; McKeefry, J. The wildland-urban interface in the United States. Ecol. Appl. 2005, 15, 799-805. 
76. Brown, D.G.; Johnson, K.M.; Loveland, T.R.; Theobald, D.M. Rural land-use trends in the conterminous United States, 1950-2000. Ecol. Appl. 2005, 15, 1851-1863.

77. Price, O.F.; Bradstock, R.A. The efficacy of fuel treatment in mitigating property loss during wildfires: Insights from analysis of the severity of the catastrophic fires in 2009 in Victoria, Australia. J. Environ. Manag. 2012, 113, 146-157.

78. Holland, M.; March, A.; Yu, J.; Jenkins, A. Land use planning and bushfire risk: CFA referrals and the February 2009 Victorian fire area. Urban Policy Res. 2013, 31, 41-54.

79. Radeloff, V.; Stewart, S.; Hawbaker, T.; Gimmi, U.; Pidgeon, A.; Flather, C.; Hammer, R.; Helmers, D. Housing growth in and near United States protected areas limits their conservation value. Proc. Natl. Acad. Sci. 2010, 107, 940-945.

80. Syphard, A.D.; Bar Massada, A.; Butsic, V.; Keeley, J.E. Land use planning and wildfire: Development policies influence future probability of housing loss. PLoS One 2013, 8, e71708.

81. Meyfroidt, P.; Rudel, T.K.; Lambin, E.F. Forest transitions, trade, and the global displacement of land use. Proc. Natl. Acad. Sci. USA 2010, 107, 20917-20922.

82. Hughes, R.; Mercer, D. Planning to reduce risk: The wildfire management overlay in Victoria, Australia. Geogr. Res. 2009, 47, 124-141.

83. Lotan, J.E. Integrating fire management into land-use planning: A multiple-use management research, development, and applications program. Environ. Manag. 1979, 3, 7-14.

84. Hansen, W.D. Generalizable principles for ecosystem stewardship-based management of social-ecological systems: Lessons learned from Alaska. Ecol. Soc. 2014, 19, 13.

85. Spies, T.A.; White, E.M.; Kline, J.D.; Fischer, A.P.; Ager, A.; Bailey, J.; Bolte, J.; Koch, J. Examining fire-prone forest landscapes as coupled human and natural systems. Ecol. Soc. 2014, $19,9$.

(C) 2015 by the authors; licensee MDPI, Basel, Switzerland. This article is an open access article distributed under the terms and conditions of the Creative Commons Attribution license (http://creativecommons.org/licenses/by/4.0/). 